Iryna Mishchenko. Variations of postmodernism in the painting of Chernivtsi artists

DOI https://doi.org/10.30525/978-9934-26-065-0-11

Iryna Mishchenko,

$\mathrm{PhD}$ of Arts, Associate Professor,

Associate Professor of Art Examination

National Academy of Managerial Staff of Culture and Arts,

Kyiv, Ukraine

https://orcid.org/0000-0002-3525-5885

\title{
VARIATIONS OF POSTMODERNISM IN THE PAINTING OF CHERNIVTSI ARTISTS
}

\begin{abstract}
The purpose of the paper. Is to analyze the development of tendencies of postmodernism in the painting of Chernivtsi in the second half of the 20th - beginning of the 21st century and to identify its features in the works of individual authors. The methodology of the study consist in the use of methods of comparison and generalization, biographical and historical approach, art analysis. The scientific novelty is to reveal the specifics of visual practices of postmodernism in the art of Chernivtsi in general and the variety of manifestations of the latter in the works of artists of different generations. The conclusions. Postmodernism in Chernivtsi painting at the turn of the 20th - beginning of the 21st centuries is represented by a fairly large number of authors and a variety of manifestations, some of which received names that are already used in publications (cryptorealism in the paintings of G. Gorbaty, firstoism in the works of S. Virsta). Perhaps the first of such variations of postmodern art was the painting of P. Hrytsyk in the 1970s and 1980s, which emerged as one of the incarnations of nonconformism. The beginning of the 1990s was a time of active development and liberation of the region's art from the conventions of socialist realism, the change in the socio-political situation in Ukraine in general contributed to that. During this period in Chernivtsi work authors with different artistic tastes, who formed individual approaches to the creation of the world of images in painting. Some of these artists relied on the classical heritage, transforming it and giving a different sound to traditional plots (V. Kovalyuk, A. Prysyazhnyuk), others sought to find mythopoetics in the renewed perception of ancient symbols, the activity of textures and the integrity of color (A. Furlet, G. Gorbaty, S. Kolisnyk), the unexpected reading of ethnic motifs (I. Lysanyuk), the emphasized vitality of the material world (O. Litvinov) or in sphere of formulas (S. Virsta). The majority of the mentioned authors also turned to non-figurative painting, because of the expressiveness of compositional structures and combinations of colors, reproducing
\end{abstract}


their perceived complexity of the universe and their own emotions (A. Prysyazhnyuk, A. Furlet, G. Gorbaty). It seems natural that the All-Ukrainian Triennial of Abstract Painting "ART-AKT" (2010-2019) has been taking place in Chernivtsi since 2010, and provides an unexpected view on the progress of modern Ukrainian non-figurative. Postmodern painting includes different variations of the embodiment of artists' own conceptual and plastic ideas, which contain not only the experience of previous epochs of artistic development, but also offer an unusual view of human and society.

Keywords: Bukovyna, fine arts, non-figurative, nonconformism, crypto-realism, firstoism.

\section{INTRODUCTION}

The relevance of the topic is in the fact that the fine arts of Chernivtsi in the middle of the 20th - beginning of the 21st centuries in general and the works of individual authors who worked in Bukovyna in particular are still a minor studied part of the visual culture of Ukraine.

It is possible to get an idea of the artistic progress of the region of the second half of the 20th - beginning of the 21st centuries mostly from Chernivtsi magazines or publications in other countries, where exhibitions of works by individual authors $[4 ; 9 ; 15]$, catalogs of personal and thematic exhibitions [12; 19] and encyclopedic publications $[6 ; 8]$ took place. The creative work of only a few artists is covered in books or albums dedicated to them $[1 ; 13 ; 16]$, articles in specialized art publications, in particular, the author of this article [11].

Today there is a lack of publications that provide an analysis of certain phenomena in the visual culture of Chernivtsi and reveal in detail the specifics of their manifestations in the work of artists. This causes interest to the chosen topic, allowing to expand the idea of Chernivtsi painting at the turn of the 20th beginning of the 21st centuries, touching on the work of at least some artists.

\section{RESULTS AND DISCUSSION}

Despite the large number of interesting artists who worked in Chernivtsi in the late 19th and early 20th centuries, the region's art has always been characterized by a fairly traditional artistic orientation. However, often the stylistic features of the art of the past and present manifestations could be found here in the works of the same masters. Thus, the signs of secession are noticeable in the works of A. Offner, E. Lipetsky, P. Vydynivsky, A. Kokhanovska, expressionism - in 
engravings by A. Kolnik, L. Kopelman, watercolors and graphic sheets by G. von Loevendal and V. Zagorodnikov. However, in the graphics and paintings of some of these authors we also notice the features of academic art, which is explained, in particular, by the fact that most of them were educated in fairly conservative educational institutions in Munich and Vienna. With the arrival of Soviet power in Bukovyna in 1940, the generation of artists changed due to the departure of many local painters and sculptors abroad and the appearance in Chernivtsi of graduates of Soviet art institutes and schools. This led to radical changes in the art of the region, where socialist realism established for a long time, based on academic principles.

Nevertheless, in the painting of Chernivtsi manifestations of resistance to socialist realism are visible since the late 1960 's. In particular, they are present in the works of S. Okstein, P. Hrytsyk, B. Tutelman.

The works of Petro Hrytsyk (b. 1944), who worked in Chernivtsi during 1968-1990 and now lives in the United States, became a vivid embodiment of nonconformism in the region, combining the compositional and coloristic achievements of the Lviv school and classical art in general and philosophical rethinking of the history and existence of human, the drama of its worldview ("Dictator", 1974; "Cemetery of Illusions", 1975; "Landscapes of childhood (two realities)", 1989), interest in non-figurative painting and the symbolism of archetypes (“Composition”, 1988; “Totemic signs (Easter egg)”, 1989). In P. Hrytsyk's painting, calm seems only external, coexisting with the internal tension of the picture ("Night", late 1980s). Reality, fantastic world created by the artist and myth intersect, they are inseparable in these paintings, in which are felt not only externally manifested emotions, but also latent expression of the author's subconscious or unanalyzable energy of creation ("Act").

It is no coincidence that the artist's paintings were included in the first thorough catalog "Ukrainian painting (60-80 years)" (1990), which stated: "Dramatic, plastically generalized, they tend to a certain symbolism, which carries clear signs of real conflicts today and at the same time are able to evoke wider associations" [18, 16] ("Eclipse", 1988).

Despite the existence of such manifestations, open opposition to socialist realism and interest in world art processes became possible only at the turn of the 1980s -1990s, which, however, led to a significant number of secondary works 
with a purely external imitation of manner and not very successful repetition of compositional techniques borrowed from the works of famous masters of modernism and modernity. Thus, paintings with supposedly surreal content, the attempts to perform non-figurative or expressionist images were common at that time. However, such imitation of motives and stylistics seemed too foreign, because they had no inner meaning, were not "experienced" and reinterpreted by their authors.

The definition given by G. Sklyarenko back in 1990 that the Ukrainian version of postmodernism is characterized by "a certain eclecticism of mastering the traditions of world culture; some conservatism of figurative and aesthetic preferences" $[18,13]$ is after all true, as at the turn of the 19th-20th centuries in the works of the same artists there were features of many currents not only of the 1970s1980 s, but also European art of the first third of the 20th century was often layered on the traditionally academic version of the composition, use of associations with classical visual or literary images. The latter was due, in particular, to the fact that the study of painting in an educational institution during the Soviet era provided an orientation exclusively to realistic art and creation according to the requirements of the external imitation of nature in combination with a programmed ideological component. However, a significant number of artists sought to break free from such restrictions, so at the turn of the 1980s and 1990s there was one of the powerful waves of national revival, "which was accompanied by artistic and cultural changes and significant phenomena in art" [17,8].

In the works of many authors not only appeared topics related to the complex history of Ukraine, but also clearly showed an open, unlike many previous decades, interest in the artistic pursuits of the 20th century - from the modernist currents of the beginning of the century to the postmodernism of the second half. The change in format of expositions also became noticeable - in addition to the usual exhibitions dedicated to certain dates of the Soviet calendar, there were conceptual projects ("Holodomor-33", 1993; "Artistic trends. Tradition and avant-garde?", 1997; "The Heart Meridian", 1997-2012 [10]) and the triennial "Ukrainian folkmodern" [20], 2009-2018; exhibition of abstract art "ART-AKT"; 2010-2019 [2; 3] etc. [14]), events of art societies ("Club of Ukrainian Artists", 1989), the participants of which had a different from the official one artistic position. This helped to change not only the figurative language of individual authors, but also the approach to the implementation of some ideas. 
Iryna Mishchenko. Variations of postmodernism in the painting of Chernivtsi artists

Among the authors of the older generation should be mentioned Artem Prysyazhnyuk (1947-2017), who performed the first non-figurative works in 1988 (stained glass for the House of Culture in Novoselytsia, Chernivtsi region), and in tapestries preferred modern artistic solutions, creating full of associations and complex color scheme composition (triptychs "Music", 1988; "Noon (Dedication to parents)", 1989; “Transformation”, 1989; “Autumn”, 1992).

A. Prysyazhniuk's attempts to express himself in easel painting coincided in time with the destruction of artistic stereotypes familiar to socialist realism. Therefore, his works of the late 1980s - early 1990s - often dramatic, emotional and sensual, repeatedly imbued with feelings of anxiety, the desire to comprehend complex events in the history of Ukraine, to find in others a response to their own and common pain ("Orphanage", 1989; "In Memory of the Unborn", 1990; "At the Threshold", 1990; "Chernivtsi. August 88"). However, despite the presence in the artist's work of socially acute themes that responded to the challenges of the time, he managed to avoid the declarative journalism, which became a sign of artistic culture of that period.

The origins of the plastic solution of the works of A. Prysyazhniuk of that time can be found in Byzantine iconography and European art of the first third of the 20th century ("Guardian Angel", 1992; "Silence", 1991; "Chervona Ruta", 1992; "Both Joy and Sadness", 2000); this was generally characteristic for the work of a large number of Ukrainian artists, who since the early 1960s sought to rediscover, rethink and transform the cultural heritage of modernism. Attempts to achieve greater picturesque freedom were more noticeable in still life, which provided endless opportunities for experimentation. And here it was possible to rely not only on the classical examples of P. Cezanne, J. Morandi, but also on the work of much closer in time and world perception of the teachers of the Lviv Institute of Applied and Decorative Arts Danylo Dovboshynsky, Karl Zvirynsky, who taught at the Lviv Institute, Odarka Kyselitsa, whose personal exhibition in Chernivtsi in 1989 was the discovery of a painting of exquisite sophistication.

Through such works the artist made the final transition to the conditionality of compositional solutions, the characteristic features of which were the use of decorative interpretation of planar elements, the expressiveness of the contour, which sometimes resembled Cezanne's approach to the image of the 
material world. Still lifes of that time are based on the clarity of linear rhythms, purist simplicity and expressiveness of silhouettes and textures of the picturesque surface.

The works of this period are marked by a tendency to monumentality, which was expressed in the conciseness of geometrized motifs, the use of large planes of local color ("Dream", 1990; “Creation”, 1991). Sometimes, A. Prysyazhniuk solved his paintings as a panel, generalizing the outlines as much as possible, getting rid of the descriptiveness inherent to the works of the previous years. The latter was not only due to the artist's appeal to rethink the artistic practices of the 20th-21st centuries, but also the influence of the Lviv Art School, which was characterized by attention to the compositional structure, and significant experience in creating tapestries.

In the future, A. Prysyazhnyuk will move in the direction of gradual release of color from isolation in subject forms, and the works will outline the principles of solution, which in 2000-2010 will determine the stylistic features of non-figurative painting of the artist - sensual, with open space of pure colors and physical sensitivity of textures ("Untitled", 2016). These works will reflect the experience of work in artistic weaving and sculpture, which will be reflected in the proportions and rhythms, in the free operation of the masses of colors, the conciseness of figurative language. The artist will avoid sharp angular shapes, but even in the seemingly chaotic layers there will be a sense of inseparable connection of elements, the interaction of which reproduces the feeling of energy that gives rise to movement. Often active small-scale intersecting diagonal elements are superimposed on each other, appear on calm and solemn large planes of color, breaking their order and static. However, in most paintings there is no impression of the confrontation of elements, masses, textures, because they all emphasize each other, making the mood of the work more emotionally expressive, forming a rational and at the same time sensual perception of the work.

The works of 2005-2016, despite the fact that the artist continues to perform traditional portraits (in particular, family members), complete the transition from thematic and journalistic works or paintings-reflections to abstract compositions in which the author seeks to solve problems of a formal nature, operating with not recognizable forms of the real world, but emphasizing the weight and selfsufficiency of the color and texture of the picturesque surface. 
Iryna Mishchenko. Variations of postmodernism in the painting of Chernivtsi artists

Among the artists who began working in the late 1980's, the desire to overcome ideological and formal constraints was particularly evident in the work of P. Kolisnyk, G. Gorbaty, A. Zhytaru, A. Furlet. Each of them has passed his own way of overcoming the orientation exclusively to the realistic school, the transformation of contemporary artistic ideas and the formation of individual stylistics.

P. Kolisnyk and G. Gorbaty - graduates of the Kyiv State Art Institute (19811987) - have been working in Bukovyna since 1987, but even after leaving Ukraine in the early 1990s they exhibited their works in Chernivtsi. Their formation was significantly influenced by the traditional study of painting with a purely academic hierarchy of genres, among which preference should be given primarily to plothistorical compositions, battle scenes or images of "socialist transformations", and mostly realistic reproduction of the world. Characteristic to the first works of these authors was the desire to recreate the beauty of the world, at most, using the achievements of the Impressionists. However, the socio-political situation in Ukraine in the late 1980s and early 1990s not only contributed to the liberation from such a view of art, but also intensified attention to the development of contemporary world art.

The works of Prokip Kolisnyk (1957-2021), who at the beginning of his work emphasized special importance of the color ("Color" was the name of the first exhibition of the artist in Chernivtsi), often resorted to experimentation, practicing the expressiveness of similar landscape motifs due to different color combinations and textures, transforming traditional iconographic schemes ("Return", 1991; "Osanna”, 2007).

Thoughtful and philosophical, sometimes even with a hint of mysticism, attitude to the world with its contradictions in the paintings of this author is combined with a refined stylization of the Byzantine icon painting tradition ("Death overcame death", “This Cup..., "Lamentation", all - 2007) and with a focus on the expressiveness and sonority of color proposed by the Impressionists and Pointillists, and the extreme nudity of the emotions of Expressionism. The latter is especially noticeable in the works of the 2010s related to modern events in Ukraine ("Man and the Fall-I", "Man and Burden", "Man and Trials" - from the series "Maidan-Tension", 2014).

In the works of Gennady Gorbaty (b. 1955) can be traced a consistent departure from the conditionally realistic art of the Soviet era and his search for 
his own plastic language and the acquaintance with Western European art of the late 20th century contributed to that, because the artist works since the early 1990s in Germany.

From the late 1980s to the early 1990s, a significant number of landscapes appeared in his work ("Years have passed", "Twilight", 1989; "Berestechko", 1991), which showed interest in creating a system of associations, especially through the use of metaphors, color and expressiveness of the picturesque surface. However, many works of this time are still characterized by narrative, in particular, paintings that reflect events in the history of Ukraine. The impetus for the creation of most historical compositions are songs, legends, poetic lines, forming an image of the past through the prism of emotional and personal perception, a certain mythologization of historical events by the author. Based on a poeticized myth, verbally defined or musically designed, the artist transforms it into somewhat unusual visual forms. Already in the early series of paintings dedicated to the era of the Cossacks or the insurgents of later times ("Awakening", 1990; "Berestechko", "Viburnum Song" (both - 1991)), there was a desire to create iconic images that will later determine the features of the artist's reflection of the real history or myth ("Babylon", 1993-1994; "Tree of Knowledge", 1994; cycle "Ukrainian mythology", "Abduction of Europe", "Samson and Delilah", "Prodigal Son" (all - 1995); "Destroyed Hope", 2009; "Garden of Eden I", 2009).

In G. Gorbaty's paintings there is a noticeable and gradual erosion of the motives of the objective world and an increase in the weight of purely formal elements - harmony or confrontation of color masses that give rise to rhythm, combination of multilayered pasty textures and scaffolding, synthesis in one painting of semantic and plastic elements of different epochs from the Middle Ages to postmodernism.

The German art critic G. Beck defined the style inherent to the artist's works as "hidden realism, similar to confusing unusual dreams, which can only be remembered very vaguely - an indistinct reflection - cryptorealism. ...Through abstract compositions of colors he reveals the graceful bodies of people, animals or fantastic symbols of the dream world. In this way, individual paintings depict the unconscious and draw the viewer into their orbit in order to find their own reality in the confrontation of ambiguity and concreteness..." [5]. 
Departing from traditional painting, G. Gorbaty later moved to compositions in which the combination of plastically expressive dynamic structures with recognizable images creates a disordered rational perception and full of sensuality phantasmagoric virtual reality, sometimes with an emphasis on theatrical performance or intuitively spontaneous desire to break free from everyday routine. Addressing the subconscious, the artist visualizes the dramatic tension or mood swings, and from the phantom of barely perceptible hints and emotions of the artist emerge unexpected and picturesque semantic parallels (cycle "Association", 2018-2020).

In the works of Vasyl Kovalyuk (1956-2013) there are both realistic, academic school works, and paintings which reminiscences the classical works, compositions where eloquent details - fragments of reality - turn into a sign and, acquiring a somewhat fantastic look, lead to the emergence of an infinite number of associations.

Even in the impressionist bouquets of the artist of the 1990s, there is a noticeable desire to free flowers from the supposedly obligatory pedestal a vase. Later, in non-figurative compositions, the artist will try to finally release the image from the vices of the real form, while emphasizing the self-sufficiency of purely picturesque means of solution. This is embodied in the polyptych "The Twelve Apostles" (1999-2000), an almost classical apostolic series whose spiritual meaning is reproduced through the color combinations and textures that overlap, shine through layers of paint, or are locked in a bright and resilient outline. In some places the image appears as a reference to the work of previous epochs, preserved in compositional parallels, fragments or in the gesture of the character. It is no coincidence that a number of works appear, as if turned to the past with its symbols ("Easter Island", 1995; "Egyptian motifs", "Abduction of Europe", 2005, etc.). A special place is occupied by biblical images, to the creation of which the artist turns, seeking to find his own interpretation of eternal truths ("Two views on betrayal", 1999; "Joy and pain of the Mother of God", 1999; "Thirteenth", 2000; "Angel outside my window", 2001; "Frankly Conversation", 2004).

In V. Kovalyuk's lyrical abstractions, plastic conventionality will become increasingly important. Softly outlined silhouettes, wrapped in flowing repeating contours, reminiscent of ancient stelae and anthropomorphic figures of the steppes, and filled with geometric elements (as the embodiment of the desire 
to acquire an internal structure), which change almost imperceptibly, but never become amorphous and indistinct.

The planes of local color are combined with surfaces covered with dynamic strokes, creating a feeling of restlessness; color spots complemented by line graphics and rhymed elements that give the images a somewhat unexpected certainty, bringing a rational beginning to the emotionality and sensuality of the painting. The works acquire an internal subconsciously tangible dynamics, manifested in a combination of various textures and softly drawn fragments, in the melody of the sound of colors (series "On the green", 2005). In the last years of the artist's life appeared works completely built on the intersection of geometric figures and lines going in different directions, leaving almost no free space on the surface of the painting. Only somewhere grey-ocher, bleached-green planes appear in soft color, giving a feeling of pause and emphasizing the restlessness of small formations and the saturation of bright tones. V. Kovalyuk actively experimented with textures created by enamel, emphasizing contrasts - tones, colors and textures, complementing the painting with rhymed and embossed elements, sawdust collage, etc.

At the exhibitions of the late 1980s and early 1990s, the paintings of Andriy Zhytaru (b. 1954) were notable for their dissimilarity to others, and sometimes struck by the feeling of hopelessness embodied in them, reproduced in the figures of women on the edge of the earth, who seems to merge with the stones of tombstones or freeze in anguish, surrounded by huge, full of sorrow, eyes-candles (“Widows", 1989, "My Malynivka", 1990). Such eyes often became a separate motif, filling the entire space of the canvas. The tragedy of the sound was emphasized by the restraint of the green-brown scale, with rare bright accents. Drawing on classical images (Mother of God, angel), the author gives them a more dramatic sound, sometimes emphasizing the inability of even such characters to change something in the world of people. Thus appears the confused angel, like a banner and a crucifix, almost powerless as the embodiment of the last, perhaps illusory, hope, who wants but is afraid to fly ("My Basarabia", 1990), and the image of a woman-bird seeking to free herself to preserve her own godlike nature.

The works of this artist are sometimes deceptively simple, full of associations and signs, and at the same time a bitter awareness of the complete destruction of the human essence, which occurs almost imperceptibly on the eyes of seemingly 
living but already petrified in their souls people. But even here, hope does not disappear, trying to free herself like a woman-bird from the darkness that envelops everything around, with candlelight eyes coming to life among it. In later works, inspired by the works of artists of the first third of the 20th century, in particular by P. Filonov, as if from a mosaic of bright fragments and geometric figures the conditionality of another reality is formed or the subconscious of the artist is open for contemplation of the artist's subconscious ("The Flying Ones", 1998).

A different version of the embodiment of one's own worldview is present in the works of artist and musician Serhiy Kolisnyk (b. 1965). Despite the traditional technique of the egg tempera, in which the painter mostly works, the compositions of the latter are distinguished by a sharp sense of modernity. Work on numerous iconographic works left in his paintings an imprint of internal balance and at the same time the pulsating tension. And his series often become a reflection of intuitive, elusive dreams and delusions or deep contemplation, embodied through the selection of laconic forms and elegance of the restrained colors (series "Rushnyk", "Arche Khata", 2019).

Ivan Lysanyuk's painting (b. 1959), which seeks to bring the reality of concrete objects into the conventionality of the two-dimensional plane of the painting, appears quite differently. Not limited to the traditional painting, he complements it with three-dimensional elements (levkas, enamels) and uses everyday things, in particular, curtains, which appear as a separate motif or background, and even become the starting point of a cycle of paintings ("Windows", 1995). Building the composition of each work in a series of rows of squares with a picturesqueembroidery filling, the author embodies his own childhood dreams of a mysterious, hidden behind the curtains, world.

A similar principle of solving the plane of the picture as a grid of squares repeatedly appears in various cycles performed by I. Lysanyuk ("Chernivtsi Album", "Ukraine" ("Ethnos")), allowing him to illustrate the idea of difference and commonality, separation and unity within one work.

A feature of the artist's work is the use of quotations of various kinds from the works of past eras. Thus, in the works from the "Chernivtsi Album" (1998) the artist repeats the famous portraits of the $15^{\text {th }}-18^{\text {th }}$ centuries, comparing them with almost photographic images of his contemporaries and emphasizing the commonality of Ukrainians, their historical heritage with the European one. 
The idea of uniqueness and at the same time unity appears in the series "Ukraine" (2019), in which the author, choosing several characteristic female characters, in each subsequent composition changes the technique and background on which the characters are depicted. By presenting busts of women in national dress and regional headdresses, against the background of geometric conditional landscapes or floral patterns that resemble Rococo or Art Nouveau tapestries, complementing them with ribbons of ornament, linen and lace textures, the artist seeks to recreate the differences of each of the regions and to emphasize the integrity of the Ukrainian ethnic group at the same time.

The tendency to conciseness of expression and sign allows I. Lysanyuk to create an almost poster image of the war, drawing among the idyllic images of Ukrainians silhouettes of heads with targets superimposed on them against the camouflage background.

Signs, however, borrowed from the field of mathematics, are the main element of a series of paintings "I am the Formula" by Svyatoslav Virsta (b. 1962). Turning to formulas as perfect expressions, the artist draws parallels between art and science, recognizing the similarity of motivations, actions and processes of cognition, trying to resolve the imaginary contradiction between the rational and emotional principles, to find a synthesis of these allegedly opposite and yet close manifestations of human spirit and creation. It is noteworthy that in an effort to synthesize mathematics and art, the artist hired as scientific consultants doctors of physical and mathematical sciences V. Maslyuchenko and I. Ogirko.

However, asserting the priority of intellectual cognition over emotional perception, S. Virsta enters into a certain contradiction with his own feelings. After all, perceiving numbers as symbols, through the combination of which in the phrase-formula one can give the most accurate description of any structure and world order in general, the author argues that such description will not leave room for subjective, individual vision. So the variety of art phenomena, in particular, melodies, color combinations, etc., can be described in formulas, once again trying to "believe in harmony in algebra". However, the value of such manifestations lies in the individual, personal perception and reproduction of the idea by the artist, which will either be leveled by a generalized formula that prevents divergence and ambiguity, or will require numerous variations, which will deprive the formula of the expected universality. 
Iryna Mishchenko. Variations of postmodernism in the painting of Chernivtsi artists

The series itself appears as a cycle of the actually existing formulas on a dark background that mimics a blackboard and related not only to the history of mathematics, but also to the biographies of specific people. Thus, one of the works - "Dynamic idealization of necessity" - is dedicated to the professor of Kyiv Polytechnic Institute Mykola Kravchuk, who taught S. Korolyov, A. Lyulka and V. Chelomey. The composition, formed by numerous thread-like lines and multi-colored formulas, superimposed on each other, denotes different periods of a scientist's life. Among them are red-colored equations and elements - they reminiscent of the death of the scientist in the Gulag.

However, among the works of the cycle there are works that the author described as not yet invented formulas for future harmony and ways to overcome chaos ("Formula of Love"). Polish art critic M. Garbach described the artist's style of work as firstoizm, linking them to Fibonacci numbers. The picture of 2017 has the same name (" $\phi$-rstoizm").

One of the most interesting Chernivtsi artists of recent years is Anatoly Furlet (b. 1958), whose compositions appear as a complex and at the same time as poeticmythologized idea not only about the visible world but about the inner essence of phenomena and the humanity in each of us. This author's painting combines many semantic layers, which gradually and unexpectedly open up as a kind of archeological cultural layers, a thin film that evaporates, leaving a feeling of meaning that can only be felt ("On the edge of the earth, for living water", 2015; "Burnt windmill", 2013; "Waiting for spring", 2016; "Composition Z", 2017).

O. Sidor-Gibelinda notes: "The figurative is painlessly used here with violent abstraction and conditionally-volumetric - with unconditionally-plane, and the latter is significantly more present. In fact, this is a "parallel reality", where the components are dominated by rather strange, alien to the logic of life, connections and are rather close to the fairy-tale-mythological one, so each of his paintings resembles a fragment of one of the lost legends, which is better to put in petroglyphs than to tell in our usual language..." $[1,15]$.

Using seemingly misty translucent scaffolding, against which the silhouettes appear more clearly, forming sometimes unexpectedly sharp color contrasts, the artist boldly combines abstract and ethnic motifs, achieving an organic integrity of the composition, which, essentially devoid of plot, is more like a parable. A. Marychevska adds "in the works of Anatoly Furlet the archetype comes to life, 
is purified, acquires deep life-giving meanings. And, becoming an object world, it, on the one hand, embodies the aesthetics of pantheism, and on the other transforming, depicts on the canvases a mythological image of life, adequate to our present" $[1,64]$.

The diversity of manifestations of postmodernism in Chernivtsi painting does not preclude, however, as in the early 20th century, the coexistence in the works of the same authors of stylistic features of several artistic directions - from the academic school, traditional reproduction of reality in full-scale forms to the interest in the latest artistic ideas and plastic-formal solutions. It is noteworthy that since 2009 Chernivtsi has become the venue for a number of all-Ukrainian projects in the format of the triennial - "Ukrainian folkmodern", "ART-AKT", "PRECHYSTA", which should reflect the many options for the development of contemporary art in Ukraine. The project "Ukrainian Folk Modern" (2009-2018) is based on the desire to reveal national identity and comprehend history and modernity in poetic, modern works. The Triennial of Abstract Art "ART-AKT" (2010-2019) is designed to represent the current state of existence of non-figurative art in Ukraine and the changes that occur not only under the influence of artistic but also sociopolitical factors. The project "PRECHYSTA" (2011-2017) "was created to initiate a discourse around the problem of "current" and "irrelevant" art" [14]. Each of these events revives interest in the artistic development not only of the region but also of the country as a whole, encourages more active communication and exchange of artistic ideas.

\section{CONCLUSIONS}

The painting of Chernivtsi in the recent decades, as well as the fine arts of the region in general, reflects all the features of the development of both Ukrainian and European visual culture of today, the ambiguous processes of forming the worldview of a human of the information society. It demonstrates the coexistence of different trends in art, different models of communication between artists and the audience and society. Existing next to the traditional reflection in painting of the surrounding world, the art of postmodernism offers various and dissimilar plastic-color incarnations of the artist's thoughts, his attitude to the artistic heritage and the latest ideas. Some artists build their paintings by quoting formal or semantic elements of the past, others 
seek to create a visual image of the present, using unusual materials and pictorial motifs.

Today it is still quite difficult to determine whether the history of art will preserve the stylistics of the individual authors (crypto-realism, firstoism), giving them wide use, or whether each of these authors, as already occured in the $20^{\text {th }}$ century, will be the only representative of the trend, and its very name will not go beyond articles in scientific or popular publications. However, such cases demonstrate the search for appropriate and correct definitions that should eventually replace the generalized and overly voluminous notion of postmodernism.

\section{REFERENCES}

1. Marychevsjka A. (ed.) (2019) Anatolij Furlet. Zhyvopys. Ghrafika. Keramika [Anatoly Furlet. Painting. Graphics. Ceramics] / uporjad. A. Marychevsjka. Kyjiv : Huss. (in Ukrainian).

2. ART-AKT. Persha vseukrajinsjka tryjenale abstraktnogho mystectva [ARTACT. The first All-Ukrainian triennial of abstract art]. (2010) Chernivci : DrukArt. (in Ukrainian).

3. ART-AKT. Tretja vseukrajinsjka trijenale abstraktnogho mystectva [ARTACT. Third All-Ukrainian Triennial of Abstract Art] (2016). Chernivci : DrukArt. (in Ukrainian).

4. Arte e Natura. La Torre di Babele (1997). Città di Imperia [in Italian].

5. Beck G. (2013). BBK Frankfurt. Künstlerinnen und Künstler. Frankfurt am Main [in German].

6. Boghajchuk M. (2005) Literatura i mystectvo Bukovyny v imenakh [Literature and art of Bukovina in names]. Chernivci : Bukrek. (in Ukrainian).

7. Bukovynsjke maljarstvo. 2002-2003. [Bukovinian painting. 2002-2003]. (2003) Chernivci : Chern. obl. orgh-cija NSKhU. (in Ukrainian).

8. Dughajeva T., Mishhenko I. (ed.) (1998) Mytci Bukovyny [Artists of Bukovina] : encykl. dovid. / avt.-uporjad.: T. Dughajeva, I. Mishhenko. Vol. 1. Chernivci : Zoloti lytavry. (in Ukrainian).

9. Illusionsmalerei und Kryptorealismus (2017). Neue Zeitung. 24. August [in German].

10. Rykhlo P. (ed.) (1998) Merydian sercja [The Heart Meridian] / upor. P. Rykhlo. Chernivci : Bukrek. (in Ukrainian). 
11. Mishchenko I. (2021). Motives of the renaissance art in the works of bukovinian artists of the 20th-21st centuries. PNAP (Periodyk Naukowy Akademii Polonijnej). Vol. 45, no. 2, pp. 94-104. DOI: https://doi.org/10.23856/4510 (in English).

12. Mystectvo Bukovyny [Art of Bukovina] (2004) : katalogh. Chernivci : Sklavija-94. (in Ukrainian).

13. Mishhenko I. (ed.) (2006) Orest Kryvoruchko [Orest Krivoruchko] : aljbom / vst. st., vporjadk. I. Mishhenko. Chernivci : Zoloti lytavry. (in Ukrainian).

14. Persha vseukrajinsjka tryjenale "ne-aktualjnogho" mystectva "PREChYSTA" [The first All-Ukrainian triennial of "non-actual" art "PRECHYSTA"] (2011) Chernivci : DrukArt. (in Ukrainian).

15. Rogowsky P. (1999). Verlassenes Nest. Main Echo. 2. Dezember. [in German].

16. Severnjuk T. (2007) Letjuchyj prominj vichnosti ... : khudozhnyk Natalja Jarmoljchuk [The Flying Ray of Eternity... artist Natalia Yarmolchuk]. Chernivci : Zoloti lytavry. (in Ukrainian).

17. Skljarenko Gh. (2003) Mizh istorijeju ta gheoghrafijeju (Do pytannja periodyzaciji ukrajinsjkogho mystectva XX st.) [Between history and geography (On the question of periodization of Ukrainian art of the twentieth century)]. Studiji mystectvoznavchi, no. 3, pp. 7-15. (in Ukrainian).

18. Ukrajinsjke malARTstvo (60-80 rr.). [Ukrainian Art (1960's-1980's)] (1990). Kyjiv : Odense : Soviart. (in Ukrainian \& English).

19. Vseukrajinsjka khudozhnja vystavka "Maljovnycha Ukrajina" [All-Ukrainian Art Exhibition "Picturesque Ukraine"] (2009). Chernivci. (in Ukrainian).

20. I tryjenale "Ukrajinsjkyj foljkmodern 2009” [I triennial “Ukrainian folkmodern 2009”] (2009). Chernivci : DrukArt. (in Ukrainian). 